\title{
Numerical study of sedimentary impact of a storm on a sand beach simulated by hydrodynamic and sedimentary models
}

\author{
Samuel MEULÉa ${ }^{a}$, Christel PINAZO ${ }^{\mathrm{a} *}$, Claude DEGIOVANNI ${ }^{\mathrm{a}}$, Jean-Paul BARUSSEAU ${ }^{\mathrm{b}}$, Maurice LIBES $^{\mathrm{a}}$ \\ ${ }^{a}$ Centre d'océanologie de Marseille, université de la Méditerranée, station marine d'Endoume, chemin de la \\ Batterie-des-Lions, 13007 Marseille, France \\ ${ }^{b}$ Centre de formation et de recherche sur l'environnement marin, université de Perpignan, 52, av. de Villeneuve, \\ 66860 Perpignan, France
}

\begin{abstract}
In marine coastal environments, storms have a major morphological impact on sand beaches. This study, part of the French Programme National d'Environnement Côtier, consisted in developing and applying hydrodynamic and sedimentary models to simulate the major processes that modify sand beaches. In order to study sediment dynamics, we developed three models to simulate waves, currents and sediment transport associated with a storm event. The wave model was a Mild Slope Equation model based on the parabolic approximation of the refraction-diffraction equation of Berkhoff. The hydrodynamic model was obtained by the depth-average of Navier Stockes' equations forced by the terms of radiation stresses induced by waves. The sedimentary model SEDSIM developed by Martinez and Harbaugh computed, by using empirical formulations, the transport, sorting, erosion and deposit of sediment. The numerical simulations computed the impact of a realistic storm event on a relatively realistic microtidal beach with wave-formed sand bars. The results show that after $15 \mathrm{~h}$ of storm, the beach receded on more than $20 \mathrm{~m}$. Two sedimentary bars and an orthogonal sand structure were removed and levelled. A tendency towards a single bar was observed. (C) 2001 Ifremer/CNRS/IRD/Éditions scientifiques et médicales Elsevier SAS
\end{abstract}

Résumé - Études numériques de l'impact sédimentaire d'une tempête sur une plage sableuse simulé avec des modèles hydrodynamiques et sédimentaires. Dans les zones littorales, les tempêtes ont un impact important sur la morphologie des plages sableuses. Cette étude intégrant le Programme national d'environnement côtier avait pour objectif de développer et d'appliquer des modèles hydrodynamiques et sédimentaires afin de simuler les processus dominants qui modifient les plages sableuses. Nous avons donc développé trois modèles pour simuler la propagation de la houle, les courants, et le transport sédimentaire associés à un coup de mer. Le modèle de houle est une approximation parabolique de l'équation de réfraction-diffraction de Berkhoff. Le modèle hydrodynamique est obtenu en intégrant sur la verticale les équations de Navier Stockes forcées par les termes de tension radiative induits par la houle. Le modèle sédimentaire Sedsim développé par Martinez et Harbaugh calcule par des formulations empiriques le transport, le tri, l'érosion et le dépôt des sédiments. Les simulations ont été faites à partir d'un scénario de tempête réelle ayant affecté une morphologie relativement réaliste de plage microtidale à barre d'avant-côte. Elles révèlent qu'après $15 \mathrm{~h}$ de tempête, la plage recule de plus de $20 \mathrm{~m}$. Deux barres d'avant côte et une structure sableuse transversale se sont déplacées et ont été aplanies. Une tendance à ce qu'une seule barre d'avant côte subsiste est observée. (C) 2001 Ifremer/CNRS/IRD/Éditions scientifiques et médicales Elsevier SAS

* Correspondence and reprints.

E-mail address: pinazo@com.univ-mrs.fr (C. Pinazo). 


\section{beach modification / numerical models / sediment transport / storm / wave-induced current}

\section{modification de la plage / modèles numériques / transport sédimentaire / tempête / courants induits par la houle}

\section{INTRODUCTION}

The present work focused on the impact of storms on non-cohesive sand beaches located in the NW Mediterranean coastal zone. From observations, it resulted that the major modifications of the coastline occurred during storms (Barusseam et al, 1994) The physical processes in a sand beach were very complex. As waves moved towards the shore, the water moved along the seabed. It encountered more friction, allowing transport of sediment. When waves broke, they caused turbulence that suspended, sorted and transported sediment backwards with undertow. Much of the energy released by breaking waves drove longshore-currents and rip-currents. Some energy continued to propagate shorewards in the swash zone, where waves were reflected backwards towards the sea.

The main sedimentary processes, modifying sand beaches morphology during a storm, are well described in the literature Ottamn. 1965: Ingle. 1966: Zenkovitch. 1967: King 1972: Barusseam et al, 1991, 1994; Blanc and Boydenot,1993). The evolution of the topographic profile resulted both from a cross-shore movement and a longshore movement. Hence, we observed a recession of the shoreline, a sand bar movement, and a levelling in the submarine beach topography.

Thus, to simulate these complex processes occurring nearshore, a coupled system of numerical models was developed (figure - ] $)$. Three models, a wave propagation model, a wave-induced current model and a sediment dynamics model, were integrated. The wave model was a Mild Slope Equation model based on the parabolic approximation of the refraction-diffraction equation of Berkhoff (1972. 1976). The hydrodynamic model solved the equations of Navier Stokes incorporating terms of radiation stresses induced by waves Longuet-Higgins 1970). The radiation stress was the excess of momentum flux due to wave propagation, which drove wave-induced currents such as longshore and rip-currents. Martinez and

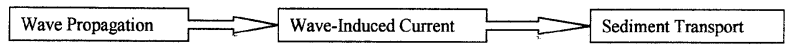

Figure 1. Coupled system of numerical models.
Harbaugh developed the sedimentary model SEDSIM Martinez and Harbaugh. 1993) It computed from empirical formulations the transport, the sorting, the erosion and the deposition of sediment.

These models were applied to a theoretical sand beach including the main typical features of the nearshore zones of the Gulf of Lions. Then, the beach presented a stable system of two quasi-continuous shore-parallel wave-formed sand bars and an orthogonal one.

\section{MODELS DESCRIPTION}

\subsection{Wave model}

The propagation of a monochromatic wave could be modelled with the elliptic equation of Berkhoff (1972. 1076:

$$
\nabla(C C g \nabla(\phi))+k^{2} C C g \phi=0
$$

in which $C$ is the phase velocity $(=\omega / k$ with $\omega$ the wave angular frequency), $k$ the wave number, $\phi$ the horizontal velocity potential and $C g$ the group velocity.

But, it was easier to project the main direction of wave propagation on the $x$-axis and to solve the parabolic equation of Berkhoff, named Mild Slope Equation:

$$
\begin{aligned}
& \frac{\partial \phi}{\partial x}=\left(i k-\frac{1}{2 k C C g} \frac{\partial k C C g}{\partial x}\right) \phi+ \\
& \frac{i}{2 k C C g} \frac{\partial}{\partial y}\left(C C g \frac{\partial \phi}{\partial y}\right)
\end{aligned}
$$

in which $i$ is an imaginary number.

However, the use of the model implied some restriction on the direction of the wave propagation. Generally, the angle was less than $60^{\circ}$ and for waves propagated from deep water to the coast with directional changes less than $90^{\circ}$.

Due to waves breaking - determined by the Battjes' test with breaking criterion 0.8-1.2 [Battjes, 1982] - the 
height of waves in surf zone was recalculated from the equation of Stive and Wind (1982).

$$
\frac{\partial \eta}{\partial x}+\frac{\eta}{4 h} \frac{\partial h}{\partial x}=A\left(\frac{h}{g T^{2}}\right)^{\frac{1}{2}}\left(\frac{\eta}{h}\right)^{2}
$$

in which $\eta$ is the surface elevation, $h$ the depth, $A$ the amplitude $(=H / 2$, where $H$ is the wave height), $g$ the acceleration due to gravity and $T$ the period.

An implicit Crank-Nicholson numerical scheme was developed to calculate wave propagation.

\subsection{Current model}

The wave model displayed the wave features as orbital and phase velocities, height, period and surface elevation, allowing the current model to solve the depth-average of Navier and Stockes' equations and to calculate the wave-induced currents from terms of radiation stress Longuet-Higgins, 1970).

$$
\begin{gathered}
\frac{\partial \bar{\eta}}{\partial t}+\frac{\partial \bar{U}}{\partial x}+\frac{\partial \bar{V}}{\partial y}=0 \\
\frac{\partial \bar{U}}{\partial t}+U \frac{\partial \bar{U}}{\partial x}+V \frac{\partial \bar{U}}{\partial y}=-g(h+\bar{\eta}) \frac{\partial \bar{\eta}}{\partial x}+\frac{1}{\rho}\left(\tau_{x x}+\tau_{x y}+\right. \\
\left.\tau_{b x}+\tau_{w x}\right)+\frac{\partial}{\partial x}\left(v_{x x} \frac{\partial \bar{U}}{\partial x}\right)+\frac{\partial}{\partial y}\left(v_{x y} \frac{\partial \bar{U}}{\partial y}\right)+f \bar{V} \\
\frac{\partial \bar{V}}{\partial t}+U \frac{\partial \bar{V}}{\partial x}+V \frac{\partial \bar{V}}{\partial y}=-g(h+\bar{\eta}) \frac{\partial \bar{\eta}}{\partial y}+\frac{1}{\rho}\left(\tau_{y y}+\tau_{y x}+\right. \\
\left.\tau_{b y}+\tau_{w y}\right)+\frac{\partial}{\partial x}\left(v_{y x} \frac{\partial \bar{V}}{\partial y}\right)+\frac{\partial}{\partial y}\left(v_{y y} \frac{\partial \bar{V}}{\partial y}\right)-f \bar{U}
\end{gathered}
$$

These are equations for conservation of momentum and energy in which $\bar{\eta}$ is the mean surface elevation, $\bar{U}$ and $\bar{V}$ the mean horizontal currents, $\tau_{b}$ the bed shear stress and $\tau_{w}$ the wind shear stress. No wind stress was considered. The diffusion $v_{i j}=0.15 H u^{*}$ was isotropic, homogeneous and effective, calculated by the equation of Fisher with the shear velocity $u^{*}$. The small tidal variation in sealevel and the Coriolis effects were negligible at the scale of our study.
The excess of momentum flux $S_{i j}$ was calculated from a formulation of Longuet-Higgins and Stewart (1964).

$$
\begin{aligned}
& S_{x x}=\frac{\rho g H^{2}}{8}\left(\left(2 n-\frac{1}{2}\right) \cos ^{2} \theta+\left(n-\frac{1}{2}\right) \sin ^{2} \theta\right) \\
& S_{y y}=\frac{\rho g H^{2}}{8}\left(\left(2 n-\frac{1}{2}\right) \sin ^{2} \theta+\left(n-\frac{1}{2}\right) \cos ^{2} \theta\right) \\
& S_{x y}=S_{y x}=\frac{\rho g}{8} H^{2} n \cdot \cos \theta \cdot \sin \theta
\end{aligned}
$$

These are components of radiation stress (excess momentum flux) where $n$ is $C_{g} / C, \theta$ the wave angle, $g$ the acceleration due to the gravity, $\rho$ the density and $H$ the mean height of waves.

An upwind and an alternative direction scheme were applied to calculate the current field. We had restricted the coast to an impermeable boundary and imposed Sommerfeld radiation conditions for lateral open boundaries Sommerfeld. 1949: Miller and Thorpe. 1981.

\subsection{Sedimentary model}

The sedimentary model SEDSIM was used to calculate the transport, the erosion, the sorting and the deposit of sediment.

First, the model calculated the total transport rate of sediment Inman and Bagnold. 1963) according to the waves and the wave-induced currents.

$$
Q=K\left(E_{b} C_{b}\right) \cos \alpha_{b}\left(v_{l} / u_{\max }\right)
$$

This represents total longshore transport rate in which $Q$ is the longshore transport rate (immersed weight), $K$ a calibration coefficient $(=0.77), E_{b}$ the wave energy density at the breaker zone, $C_{b}$ the group velocity at the breaker zone, $\alpha$ the angle of wave incidence at the breaker zone, $v_{l}$ the average longshore velocity and $u_{\max }$ the maximum orbital velocity.

Second, at each grid point, a local transport rate $Q_{i, j}$ was calculated in function of the local maximum orbital velocity (Horikawa.1988).

$$
Q_{i, j}=Q\left(\frac{u_{i, j}}{u_{\mathrm{tot}}}\right)
$$

represents the local transport rate in which $u_{i, j}$ is the maximum orbital velocity at grid location $(i, j)$ and $u_{\text {tot }}$ the sum of maximum orbital velocity. 
Third, the conservation of sediment determined the amount of sediment available to be moved. These thickness of the upper sediment cell $(i, j)$ is the active layer thickness $\Delta z$. It changed during simulation to:

$$
\Delta z=\frac{Q_{i, j}}{\Delta x \Delta y} \Delta t
$$

The variation of the thickness $\Delta z$ was calculated from the local transport rate $Q_{i, j}$ the size of the grid-cell $(\Delta x \Delta y)$ and the time step $\Delta t$.

Fourth, the sorting was calculated from different transport efficiencies determined from respective turbulence effects, fall velocity, critical shear stress and bottom shear stress of different grain sizes Slingerland and Smith 1986: Komar, 1989: Martinez and Harbaugh. 1993).

$$
V o l=\sum_{k s} V o l \cdot \varepsilon_{k s}
$$

in which $\mathrm{Vol}$ is the displacement volume, $k s$ a type of grain and $\varepsilon_{k s}$ the relative capacity of transport of each grain size.

Finally, after being transported by wave-induced currents, the sediment was deposited on the upper sediment cell.

\subsection{Numerical methods}

Four grids were used in this work (figure 2). Three two-dimensional grids in $(x, y)$-space represented the bathymetry, the current field and the sediment transport. A three-dimensional grid in $(x, y, \theta)$-space computed the wave field. Each grid could have different resolution and orientation in $(x, y)$-space as long as the current grid was covered by the wave grid. The values of $\Delta x$ and $\Delta y$ were based on the numerical stability criterion of CourantFriedrichs-Levy (CFL) described by Vreugdenhil (1989).

$$
\Delta t \leq \frac{1}{\sqrt{g h}}\left(\frac{1}{\Delta x^{2}}+\frac{1}{\Delta y^{2}}\right)^{-\frac{1}{2}}
$$

represents the CFL criterion in which $g$ is the acceleration of gravity and $h$ the depth in deep water.

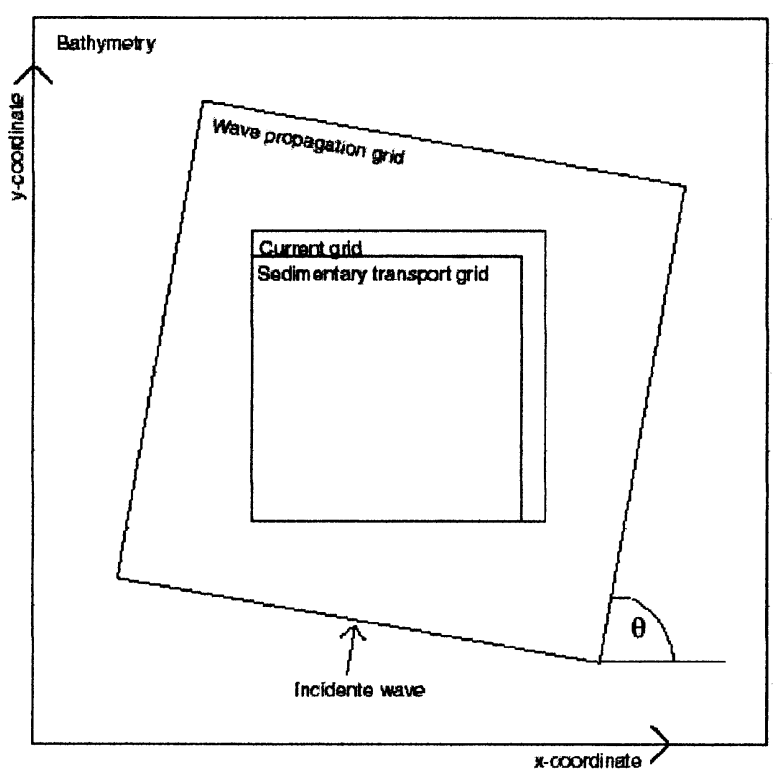

Figure 2. Numerical grid location.

The very high spatial resolution required in coastal areas would demand too many computer capabilities. For reasons of efficiency, the computations were made on regular grids.

To assess the behaviour of the models in regard to hydrodynamics problems, they were applied to a rather basic idealised situation for which the results could be compared with information in the literature (test on a circular bay from the French Laboratoire National d'Hydraulique). These results were deemed satisfying.

\section{SIMULATION CONDITIONS}

To test the models in relatively realistic geophysical conditions, the models were applied to a stable system of quasi-continuous shore-parallel wave-formed sand bars. This type of area was chosen because it is a common type of beach in the nearshore zone of the Gulf of Lions. The model results could be also compared with the results of a well-documented field. The shape, the number, and the degree of stability of the sand-bars is variable along the coast, following its local exposure to the dominant waves, the proximity of headlands, the slope and grain-size equilibrium, the volume of sediment in movement and the presence of sea defence structures 


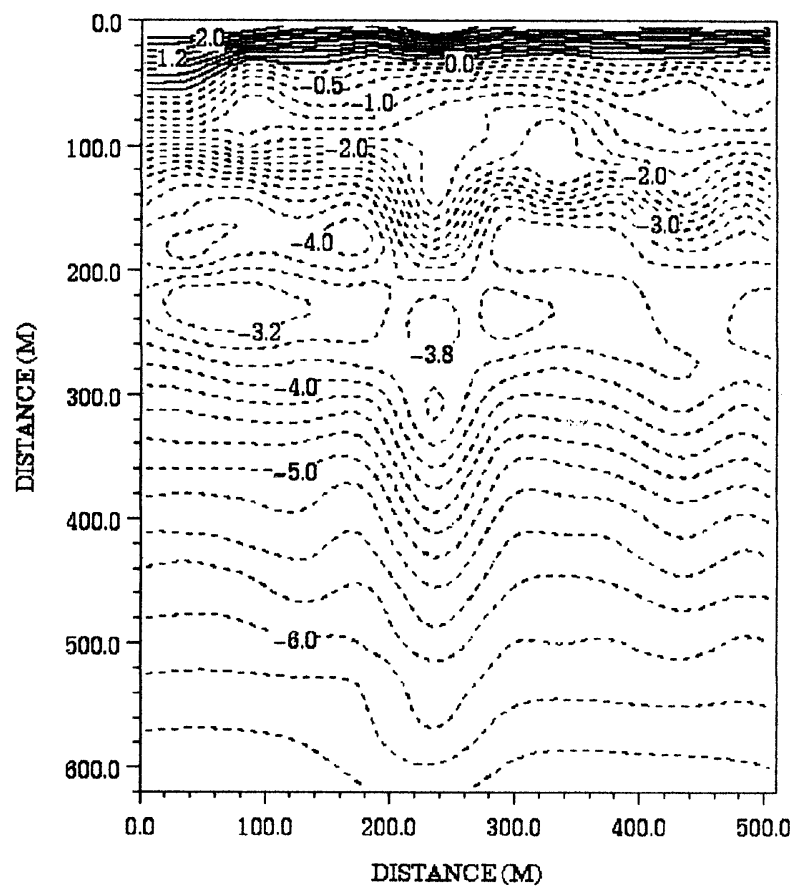

Figure 3. Initial bathymetry of the theoretical beach. Units in meters. The equidistance is $0.25 \mathrm{~m}$.

Ungle, 1966: Zenkovitch, 1967: Barusseaw_and_SaintGuily, 1981: Barusseaw et al, 1991, 1994).

\subsection{Initial bathymetry of the beach}

We chose to test the models on an initial coastal zone $(500 \times 610 \mathrm{~m})$ (fgure 3 ) with two shore-parallel waveformed bars developed in the nearshore: an inner-bar at a distance of $80 \mathrm{~m}$ from the shoreline and an outer-bar at a distance of $200 \mathrm{~m}$ from the shoreline. In addition, there was another sand structure orthogonal to the shore in the middle of the computed field. This sand bar was assimilated to an oblique bar. However, in sand beaches, an orthogonal structure could be present Barcilon and Lau 1973). Further, the beach was rather plane with a global slope of $1: 80$.

The nature of sediments was assessed from studies of sediment core samples. We imposed four grain size characteristics with a coherent spatial distribution. The amount of sediment in each point of the grid was estimated according to the gradual passage from coarse size near the coast towards fine size in deep water.

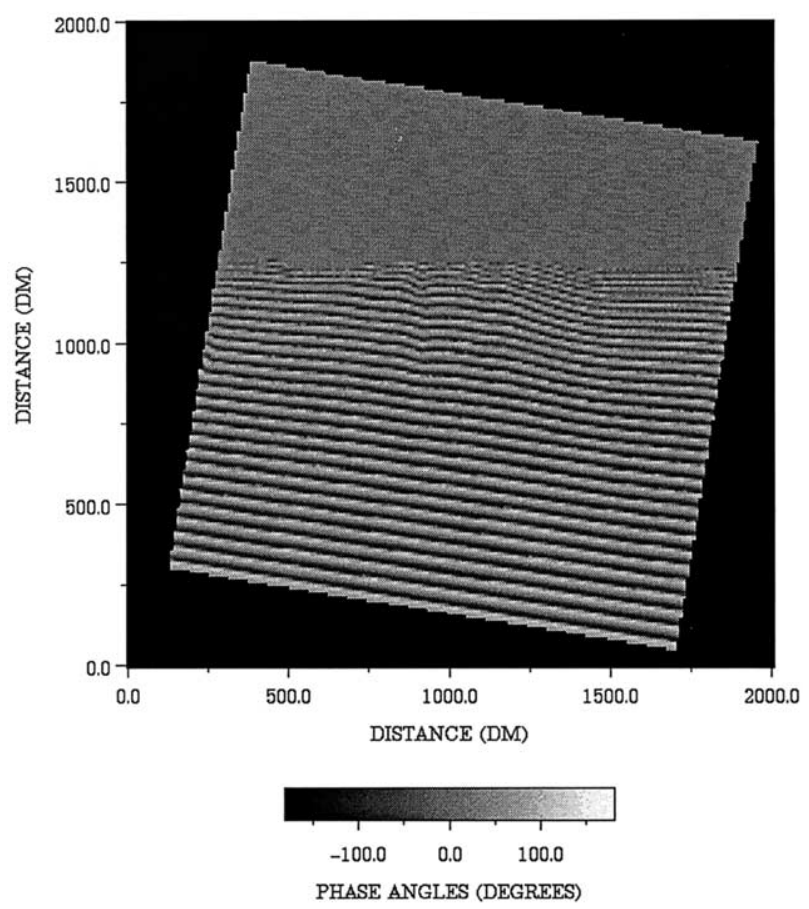

Figure 4. Phase angles of a wave propagating with an incidence of $80^{\circ}$.

\subsection{Hydrodynamics conditions}

For a realistic field situation, we chose to compute for a 15 -h storm event. In this work, we changed the features of waves each $4 \mathrm{~h}$. In this way, the model system was run with an increase of the height and the period. The waves penetrated the area in deep water at an incidence angle of $\theta=80^{\circ}$.

\section{RESULTS}

In figure 4 we can see the phase angles of the major wave occurring after $12 \mathrm{~h}$ of storm. Indeed, the major modifications occurred with this major wave regime. We showed that when wave moved towards the shore, there was a relatively important refraction. Thus, the crest line of wave was fitted with isobaths geometry. The pattern of the wave propagation was modified on the different sand structures, and more especially on the location of the orthogonal structure.

In figure 5, arrows show the wave-induced currents for the previous wave regime superimposed on initial 


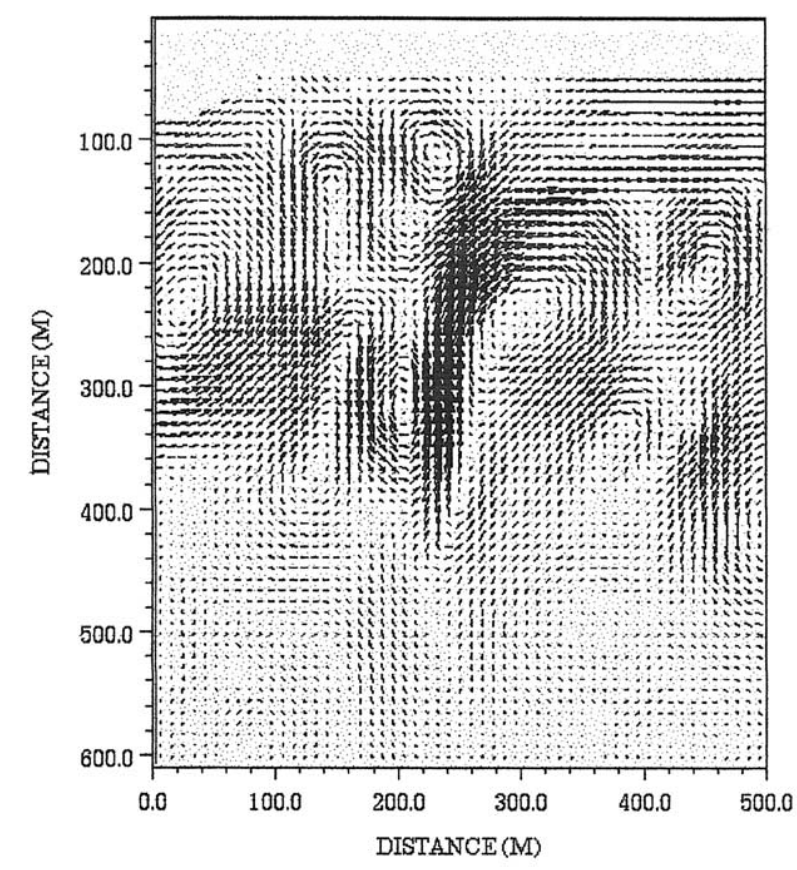

Figure 5. Wave-induced current field $\left(\rightarrow=2.88 \mathrm{~m} \cdot \mathrm{s}^{-1}\right)$.

bathymetry. The currents were more intense in the surf zone. A shore parallel movement was settled in the inner-interbar. However, this wave-generated longshorecurrent was limited to the right of the computational grid. The presence of the orthogonal structure divided the currents and in this way created disturbance and different cells of secondary circulation.

As a result of sediment transport, it is interesting to examine where the zones of deposit and transport are located. In figure 6 , dashed lines show erosion and solid lines show deposition of sediment. The coastline and the inner-bar were in erosion. Moreover, the intensive bottom erosion occurred mainly in front of the outer-bar and the orthogonal structure submitted to the waves. There was erosion, transport and deposit behind the outer-bar and the orthogonal structure. But usually, an erosional trend could be observed.

So after these modifications, the bathymetry after $15 \mathrm{~h}$ of simulation was considerably reshaped (figure 7 ). The coastline receded on more than $20 \mathrm{~m}$. The inner-bar, the outer-bar and the orthogonal structure were levelled and moved shorewards, in the direction of the wave propagation. Two sand bars remained but a tendency towards a single bar profile seemed to begin.

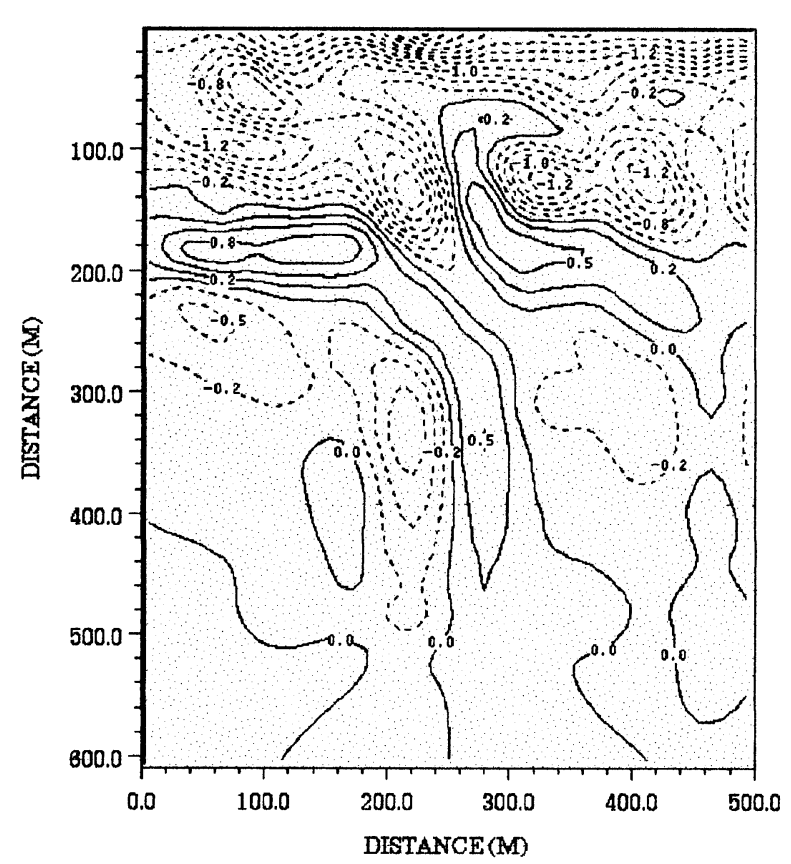

Figure 6. Zones of erosion and deposit after $15 \mathrm{~h}$ of simulation. Dashed lines (---) show erosion in meters and solid lines (-) show deposition of sediment in meters.

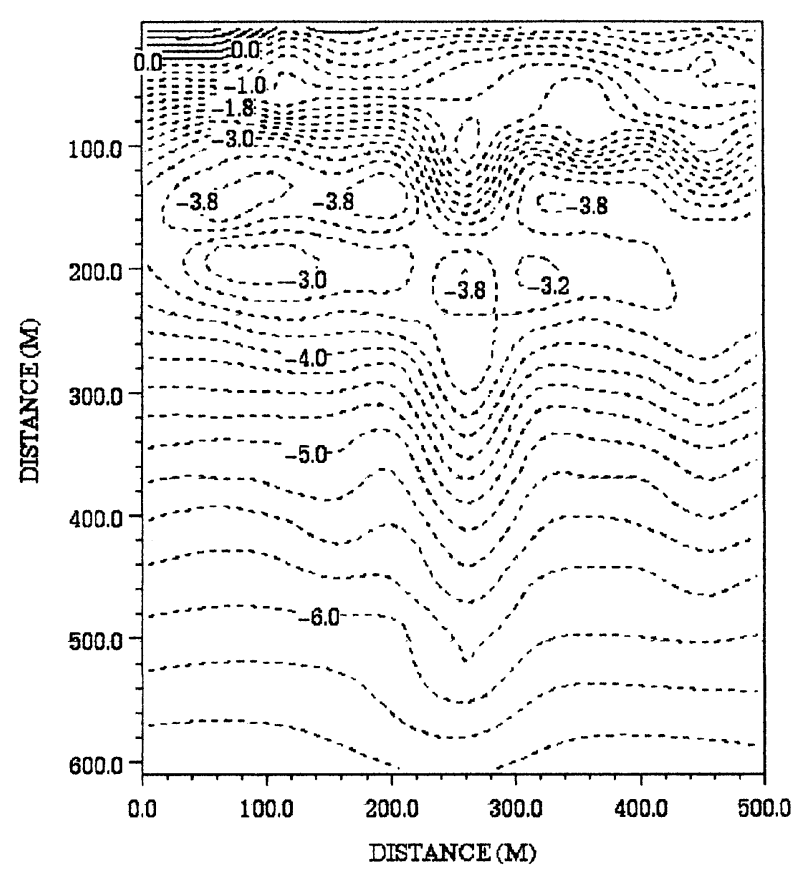

Figure 7. New bathymetry after $15 \mathrm{~h}$ of simulation. Units in meters. The equidistance is $0.25 \mathrm{~m}$. 


\section{CONCLUSION}

The wave propagation towards the coast released energy that created longshore-currents and rip-currents. The corresponding sediment movement induced a net longshore sediment transport, a recession of the shoreline, and a sand bar movement. The overall wave-energy distributions induced a topographic feed-back effect complicating the sediment movement patterns. The transport directions inferred from the morphological evolution.

In a qualitative view, the results of this study were in good agreement with the morphological changes, observed in the literature after a storm on a beach with wave-formed sand bars @ngle, 1966: Ottamn. 1965. Zenkovitch. 1967: King. 1972: Barusseau et al. 1991 1994: Blanc and Poydenot 1993).

The model tried to simulate the real phenomena occurring in a beach. Sedimentary models seemed to give goods results at a large scale KKim et al_ 1997: L L _ _ and Ridd 1997: Zhang et al. 1998) The sand bar formation and theirs movements in the nearshore zone, described by Barusseau and coworkers Barusseam and Saint-Guily 1981: Barusseau et al. 1991. 1994) could even be simulated Boczar-Karakiewicz and Davidson-Arnott 1987: Mei and Liw. 1993). In this way, we observed that the inner-bars were levelled, and the outer-bars moved towards the sea. In this study, the sedimentary movement toward the sea did not exist. However, we noticed an accumulation of sand offshore, out of the valid numerical grid.

The formation of sand bars Boczar-Karakiewicz and Davidson-Arnott. 1987) could be caused by breaking waves Komar.1976:_Barusseau_et_al_ 1994 or by infragravity waves. In this study, the coupled system of numerical models did not compute the infragravity waves. But considering the results, these models were very encouraging. We could imagine as did Wright et al 1991 that incident waves cause shoreward transport whereas the interactions of incident waves with infragravity waves cause seaward transport.

The presented models may be powerful tools for studying beach modifications, predicting the main tendencies and estimating the optimal features of coastal builds. The next step is the validation of the model. We will apply the model to a realistic field like the Beach of Sète studied in the PNEC.

\section{Acknowledgements}

This paper presents the results of a research study supported by the French Programme National d'Environnement Côtier (PNEC Art 7). The authors thank Principia R.\&D. for its collaboration in the development of the hydrodynamic numerical models and John W. Harbaugh for the version 3.0 of the sedimentary model SEDSIM.

\section{REFERENCES}

Barcilon, A.I., Lau, J.P., 1973. A model of formation of transverse bars. J. Geophys. Res. 78, 2656-2664.

Barusseau, J.P., Saint-Guily, B., 1981. Disposition, caractère et formation des barres d'avant-côte festonnées du Golfe du Lion. Oceanol. Acta 4, 297-303.

Barusseau, J.P., Brisseaux, L., Drapeau, G., Long, B., 1991. Processus hydrodynamiques et morphosédimentaires de l'environnement des barres d'avant côte du littoral du golfe du Lion, Oceanol. Acta, Actes du Colloque International sur l'environnement des mers épicontinentales, Lille, 20-22 mars 1990, Special issue 11, pp. 163-176.

Barusseau, J.P., Radulescu, M., Descamps, C., Akouango, E., Gerbe, A., 1994. Morphosedimentary multiyears changes on a barred coast (Gulf of Lions, Mediterranean Sea, France). Mar. Geol. 122, 47-62.

Battjes, J.A., 1982. A case study of wave height variations due to currents in a tidal entrance. Coast. Eng. 6, 47-57.

Berkhoff, J.C.W., 1972. Computation of combined refractiondiffraction. Proc. 13th Int. Conf. Coast. Eng. Vancouver.

Berkhoff, J.C.W., 1976. Mathematical models for simple harmonic linear water waves, wave diffraction and refraction. Delft Hydraulics Laboratory, Publ. No. 163.

Blanc, J.J., Poydenot, F., 1993. Le rivage de Faraman en Camargue (SE. France): un géosystème côtier en déséquilibre; méthode d'étude, conséquences pratiques. Géol. Médit. XX, 75-87.

Boczar-Karakiewicz, B., Davidson-Arnott, R.G.D., 1987. Nearshore bar formation by non-linear wave processes, a comparison of models results and field data. Mar. Geol. 77, 287-304.

Horikawa, K., 1988. Nearshore Dynamics and Coastal Processes, Theory, Measurement, and Predictive Models. University of Tokyo Press, Tokyo, pp. 1-522.

Ingle, J.C. Jr, 1966. The Movement of Beach Sand. Elsevier, New York.

Inman, D.L., Bagnold, R.A., 1963. Littoral processes. In: Hill, M.H. (Ed.), The Seas: Ideas and Observations on Progress in the Study of the Seas. Wiley \& Sons, New York, pp. 529-553.

Kim, S.C., Wright, L.D., Kim, B.O., 1997. The combined effects of synoptic-scale meteorological events on bed stress and sediment transport on the inner shelf of the Middle Atlantic Bight. Cont. Shelf Res. 17, 407-433.

King, C.A.M., 1972. Beaches and Coasts. Edward Arnold, London.

Komar, P., 1976. Beach Process and Sedimentation. Prentice-Hall, Englefield Cliffs, New Jersey. 
Komar, P., 1989. Physical processes of waves and currents and the formation of marine placers. CRC Crit. Rev. Aquat. Sci. 1, 393-423.

Longuet-Higgins, M.S., 1970. Longshore currents generated by obliquely incident sea waves 1 and 2. J. Geophys. Res. 75, 6778-6801.

Longuet-Higgins, M.S., Stewart, R.W., 1964. Radiation stresses in water waves - a physical discussion with application. Deep-Sea Res. 11, 529-563.

Lou, J., Ridd, P.V., 1997. Modelling of suspended sediment transport in coastal areas under waves and currents. Estuarine Coast. Shelf Sci. 45, 1-16.

Martinez, P.A., Harbaugh, J.W., 1993. Simulating Nearshore Environments, Computer Methods in the Geosciences. Pergamon Press.

Mei, C.C., Liu, P.L.F., 1993. Surface waves and coastal dynamics. Annu. Rev. Fluid Mech. 25, 215-240.

Miller, M.J., Thorpe, A.J., 1981. Radiation conditions for the lateral boundaries of limited-area numerical models. Quart. J. R. Met. Soc. 107, 615-628.
Ottamn, F., 1965. Introduction à la géologie marine et littorale. Masson, Paris.

Slingerland, R., Smith, N.D., 1986. Occurrence and formation of water-laid placers. Ann. Rev. Earth Planet. Sci. 14, 113-147.

Sommerfeld, A., 1949. Partial differential equations: Lectures in Theoretical Physics, No. 6. Academic Press.

Stive, M.J.F., Wind, H.G., 1982. A study of radiation stress and set up in the nearshore region. Coast. Eng. 6, 1-25.

Vreugdenhil, C.B., 1989. Computation Hydraulics, An introduction. Springer.

Wright, L.D., Boon, J.D., Kim, S.C., List, J.H., 1991. Modes of cross-shore sediment transport on the shoreface of the Middle Atlantic Bight. Mar. Geol. 96, 19-51.

Zenkovitch, V.P., 1967. Processes of Coastal Development. Interscience, New York.

Zhang, Y., Swift, D.J.P., Yu, Z., Jin, L., 1998. Modelling of coastal profile evolution on the abandoned delta of the Huanghe River. Mar. Geol. 145, 133-148. 